The main results show that 500 p.p.m. of acetyl salicylic acid improve growth, food intake and food efficiency as well as the health of the animals.

The antibiotic supplementation of 100 p.p.m. results in a spectacular increase of the performances in the animals submitted to a stress when they are conveyed to another piggery at a weight of about $\mathrm{Ir} \mathrm{kg}$ ( $\mathrm{I} 5$ days after early weaning). This improvement is due both to an increase of the food intake and to an increase of the food efficiency. The effect of the antibiotic supplementation upon the mortality of the piglets was also considerable, whereas the effect upon the decrease of the morbidity was real, but difficult to estimate.

\title{
INFLUENCE DE L'ADDITION DE CUIVE AU RÉGIME DU PORC SUR SES CARACTÉRISTIQUES DE CROISSANCE ET DE COMPOSITION CORPORELLE
}

\author{
A. RÉRAT \\ Station de Recherches sur l'Elevage des Porcs, \\ Centre national de Recherches zootechniques, I. N.R. A., \\ 78 - Jouy-en-Josas
}

\section{RÉSUMÉ}

Une expérience est décrite dans laquelle sont comparées la valeur nutritionnelle $\mathrm{du} \mathrm{SO}_{4} \mathrm{CU}$ utilisé en tant qu'adjuvant alimentaire à dose relativement élevée ( 25 et 25 o.p.m.) et celle d'un antibiotique classiquement utilisé en alimentation porcine, la virginiamycine (à raison de 20 p.p.m.). Les résultats obtenus permettent de conclure à une amélioration de l'efficacité nutritionnelle du régime et de la vitesse de croissance sous l'influence des deux doses de sulfate de cuivre ; par contre, l'àdiposité des carcasses tend à s'élever. Dans nos conditions expérimentales, il existe une action additive entre $\mathrm{SO}_{4} \mathrm{CU}$ et antibiotique. Compte tenu du prix peu élevé du sulfate de cuivre en comparaison avec celui des antibiotiques, ce prođuit présente un intérêt indéniable en élevage porcin, à condition de ne pas en incorporer des doses trop importantes (supérieures à $25^{\circ}$ p.p.m.).

\author{
SUMMARY \\ GROWTH CHARACTERISTICS AND BODY COMPOSITION OF PIGS \\ AS INFLUENCED BY THE ADDITION OF COPPER IN THEIR DIETS
}

An experiment is described during which we compared the nutritional value of $\mathrm{SO}_{4} \mathrm{CU}$ used as food additive at relatively high doses (I25 and 250 p.p.m.) and that of Virginiamycine, an antibiotic very often used in pig feeding (at a level of 20 p.p.m.). The results obtained show an improvement of the nutritional efficiency of the diet and of the growth rate as influenced by the two doses of copper sulphate; on the other hand, the adiposity of the carcasses tends to increase. 
Under our experimental conditions, there is an additive action between $\mathrm{SO}_{4} \mathrm{CU}$ and the antibiotic. Taking into account that copper sulphate is not very expensive compared to antibiotics, this product is of undeniable interest for pig breeding, provided that the doses used are not too high (superior to 250 p.p.m.).

DIVERS

MISCEL,I,ANEOUS

\title{
(ESTROGÈnES ET PROGESTOG ÈnES AU COURS DU GYCLE DE REPRODUCTION DEILA TRUIE
}

\author{
P. ROMBAUTS, J. FEVRE et M. TERQUI \\ Station centrale de Physiologie animale, \\ Centre national de Recherches zootechniques, I. N.R.A., \\ 78 - Jouy-en-Josas
}

\section{RÉSUMÉ}

La sécrétion de progestérone au cours du cycle ostrien de la truie commence dans les $24 \mathrm{~h}$ suivant l'œstrus et se poursuit pendant la phase lutéale, avec un maximum au ro jour du cycle. La synthèse de progestérone s'arrête brutalement vers les $\mathrm{I}_{4}{ }^{\mathrm{e}}-\mathrm{I} 5^{\mathrm{e}}$ jours du cycle, moment où commence la régression des corps jaunes. A ce stade, la sécrétion d'œestrone, faible jusqu'alors, augmente (4o à $60 \mu \mathrm{g}$ éliminés par $24 \mathrm{~h}$ dans l'urine) jusqu'à l'œstrus suivant. Cette sécrétion d'œestrogènes induit les modifications caractéristiques de l'œestrus et provoque, par l'intermédiaire de LH, l'ovulation.

$\mathrm{Au}$ cours de la gestation, la sécrétion de progestérone par les corps jaunes reste à peu près constante. Cette progestérone ovarienne est indispensable au maintien de la gestation car le pla centa de truie ne sécrète pas de progestérone. L'élimination urinaire d'œestrone présente un aspect caractéristique : après des valeurs basses, il y a un premier maximum d'excrétion le $28 \mathrm{e}$ jour ( 2 à $2,5 \mathrm{mg}$ par $24 \mathrm{~h}$ ) qui peut permettre le diagnostic de gestation. Suivent alors des valeurs basses jusque vers le $8 \mathrm{o}^{\mathrm{e}}$ jour, stade où l'élimination redevient progressivement importante, les valeurs maximales se trouvant au voisinage de la parturition ( 15 à $20 \mathrm{mg}$ par $24 \mathrm{~h}$ ). La sécrétion d'œestro gènes étant d'origine fœto-placentaire, on peut ainsi contrôler la viabilité des fœetus et prévoir l'ordre de grandeur de la portée.

\section{SUMMARY}

\section{ESTROGENES AND PROGESTOGENES DURING THE ESTRUS CYCLE OF THE SOW}

The secretion of progesterone during the estrus cycle of the sow begins in the 24 hours folluwing the estrus and continues during the luteal phasis, with a maximum on the Ioth $^{\text {th }}$ day of the cycle. The progesterone synthesis suddenly ceases on the $\mathrm{I}_{4}^{\text {th }}$ or $\mathrm{I}^{\text {th }}$ day of the cycle at the begin- 